\title{
British Diplomacy in Switzerland (1689-1789) and Eighteenth Century Diplomatic culture
}

\section{Christopher Storrs}

\section{(2) OpenEdition \\ 12 Journals}

\section{Electronic version}

URL: http://journals.openedition.org/edl/266

DOI: $10.4000 /$ edl. 266

ISSN: 2296-5084

\section{Publisher}

Université de Lausanne

\section{Printed version}

Date of publication: 15 September 2010

Number of pages: 181-216

ISBN: 978-2-940331-23-9

ISSN: 0014-2026

\section{Electronic reference}

Christopher Storrs, « British Diplomacy in Switzerland (1689-1789) and Eighteenth Century Diplomatic culture », Études de lettres [Online], 3 | 2010, Online since 10 December 2013, connection on 19

December 2020. URL : http://journals.openedition.org/edl/266 ; DOI : https://doi.org/10.4000/edl.266 


\section{BRITISH DIPLOMACY IN SWITZERLAND (1689-1789) AND EIGHTEENTH CENTURY DIPLOMATIC CULTURE}

This essay explores the men who represented England (Britain following the Union of England and Scotland in 1707) between 1689 and 1789. It looks at what they were expected to do, at their origins, and at their careers. Reflecting the relative lack of importance of Switzerland in British diplomacy in the eighteenth century, resident British missions there were infrequent. In addition, most British diplomats sent to Switzerland were of relatively inferior social status, and most were appointed at a very junior diplomatic rank. In conclusion, British diplomacy and diplomats in Switzerland do not easily fit into the "diplomatic culture" which some historians have identified as developing in the eighteenth century and which clearly applies to the more important Courts to which Britain sent representatives after 1689.

England's position in Europe was transformed in the long eighteenth century (1689-1815), following the Glorious Revolution of 1688-1689, when king James II was replaced on the throne by his daughter, Mary and her husband, William of Orange, or William III. Before that event, England was a significant but not a major power, and in the decades before 1688 had played a self-effacing role in Europe. After the Revolution, however, England - Great Britain following the Union with Scotland in 1707 - rapidly emerged as one of the Great Powers, and one of the leaders of successive efforts to contain Bourbon France in what some historians have termed the "Second Hundred Years War" ${ }^{1}$. To play this role, Britain relied on a number of key instruments, including

I. G. Gibbs, "The Revolution in Foreign Policy”; J. Black, "The Revolution and the Development of English Foreign Policy" and D. Mckay and H. M. Scott, The Rise of the Great Powers 1648-1815, passim. 
its army, its fleet and - because these were expensive - an impressive administrative structure which provided the funds for these ${ }^{2}$. But another, and far less expensive, instrument of British policy after 1689 was an expanding diplomatic network across Europe. This enhanced pattern of diplomatic contacts embraced, to a degree it had not done before $1688^{3}$, Switzerland, i.e. the Helvetic Body (the confederation of thirteen cantons, its associates and allies), the republic of Geneva and the Grisons ${ }^{4}$.

What follows is less concerned with the detail of diplomatic activity - policy and its implementation in the form of bilateral negotiations which is the traditional focus of diplomatic history. The latter has largely fallen out of fashion after once being one of the pre-eminent types of historical investigation. Instead, and reflecting the emergence in recent decades of what is sometimes called the "New Diplomatic History" 5 , I shall focus on the diplomats who resided in Switzerland, negotiated there, and reported from there. I will begin by considering the broad aims and objectives, and the methods of British policy in Switzerland, because these would affect when a man was sent, and for how long, as well as what sort of man he was and the diplomatic rank he enjoyed, all of which I will then discuss.

British diplomats, and the structure within which they operated in this period - the British diplomatic "service", if the latter is not too

2. Ch. Storrs (ed.), The Fiscal-Military State in Eighteenth Century Europe and J. Brewer, The Sinews of Power.

3. According to G. M. Bell, A Handlist of British Diplomatic Representatives 15091688 , p. $280-282$, England sent just twelve ministers to Swizerland in that period; the last was there between 1655 and 1665-1667; cf. also L. A. Robertson, "The Relations of William III with the Swiss Protestants, 1689-1697”. It is not therefore surprising that there was some uncertainty, 1688-1689 in London about which of the two Secretaries of State (the one for the North, or the one for the South) was responsible for relations with Switzerland; Duke of Shrewsbury to William Blathwayt, Whitehall, 19 May 1696, HMC Buccleuch, II/1, p. 334.

4. For a very brief explanation of what "Switzerland" meant in this period, cf. L. A. Robertson, "The Relations of William III with the Swiss Protestants, 16891697 ", p. 154, and D. B. Horn, Britain and Europe in the Eighteenth Century, p. 310311. Unfortunately, British diplomacy in Switzerland has not been studied in the same detail as has that of France, for which see E. Rott, Histoire de la représentation diplomatique de la France auprès des Cantons suisses et leurs alliés et de leurs Confédérés.

5. For "old" and "new" diplomatic history, cf. J. Black, A System of Ambition?, p. $7 \mathrm{ff}$. 
anachronistic a term - have not been ignored by historians, as the following pages will reveal ${ }^{6}$. Nevertheless, those diplomats who served in Switzerland tend to be overlooked in favour of men of greater prominence and achievement in other postings. Besides bringing into view Britain's rather shadowy representatives in Switzerland, I hope to use them to engage with some of the arguments or conclusions of various historians, including H. M. Scott, for whom the diplomatic culture of eighteenth century Europe was increasingly francophone, "resident", and noble ${ }^{7}$. At the same time, it should be possible to throw light on questions such as the degree of professionalism of British diplomats and the British diplomatic service ${ }^{8}$.

The main source for what follows are the instructions issued by the Secretary of State's (and from 1782 the Foreign Secretary's) office in London and successive British ministers in Switzerland ${ }^{9}$, and the official correspondence which the latter maintained with the former, and which is housed in the National Archives in London, in the State Papers; copies of these letters can sometimes also be found in the British Library, in London. Also useful, where it throws light on the British representatives in Switzerland, are the letters of British ministers elsewhere, notably in Paris and Turin, those of the British representatives in Switzerland with the ministers there of other sovereigns, and those of foreign diplomats ${ }^{10}$.

6. British ministers in Switzerland are not prominent in either D. B. Horn, The British Diplomatic Service 1689-1789 or J. Black, British Diplomats and Diplomacy 1688-1800.

7. H. M. Scott, "Diplomatic culture in old regime Europe".

8. D. B. Horn, The British Diplomatic Service 1689-1798, p. 13.

9. Unfortunately, these have not been published as have the French instructions, cf. G. Livet (éd.), Recueil des Instructions aux Ambassadeurs et Ministres de France - but the British instructions are less substantial anyway than the French. For John Burnaby's instructions (1743), cf. M. Meier, Die diplomatische Vertretung Englands in der Schweiz im 18. Jahrhundert, p. 138. Where they survive, the ministers' accounts throw useful additional light on their activities; for Thomas Coxe's bills of extraordinaries, Mar. 1690-Aug. 1692, cf. earl of Nottingham (Secretary of State) to Commissioners of Treasury, 21 Feb. 1693 (OS), CSPD, 1693, p. 40-43, and warrant for payment of Hervart's extraordinary expenses, Sept. 1694-Mar. 1695, CSPD, 1695, p. 66.

Io. William Aglionby corresponded with the representative there of the Duke of Savoy, Pierre Mellarède, in 1703-1704, AST/LM/Svizzera, mazzo 36. 


\section{Role}

British diplomatic method or practice would also shape missions. British ministers generally preferred, for various reasons, to negotiate through their representatives abroad, although this was not consistently adhered to ${ }^{11}$. It might be difficult in Switzerland, for two reasons. Firstly, there was the religious divide, further evidence that - contrary to a well-entrenched belief - religion remained a complicating factor in international relations after $1648^{12}$. This restricted the scope of British representation in Switzerland, where British ministers were only accredited to the Protestant cantons until the later eighteenth century ${ }^{13}$. Before then, Britain's depended on its Catholic allies - to fill, or to try to bridge the gap. In 1690, during the Nine Years War, or War of the League of Augsburg (1688-1697), the ministers of the Emperor and Spain sought to ensure that Coxe was received by the Catholic cantons, as a preliminary to his appearance before the General Diet, in a situation in which Louis XIV's representatives used the religious argument to secure a veto on the part of his Swiss co-religionists ${ }^{14}$. In the War of the Spanish Succession, too, Britain's Catholic allies were expected to facilitate British diplomacy with the Catholic cantons. The same was true after 1713. The second limiting factor was the republic of Geneva's unwillingness, in wartime, to receive an envoy from Britain for fear of provoking the French king (below).

The missions of all those sent abroad, including to Switzerland clearly had to fit into, and were shaped by the larger aims and objectives of

II. D. B. Horn, The British Diplomatic Service 1689-1789, p. 6; Black, British Diplomats andDiplomacy 1688-1800, p. $64 \mathrm{ff}$.

I2. On the religious divide in Switzerland and its implications, cf. D. B. Horn, Britain and Europe in the Eighteenth Century, p. $311 \mathrm{ff}$. For a European perspective, cf. D. Onnekink (ed.), War and Religion after Westphalia 1648-1713.

13. D. B. Horn, Britain and Europe in the Eighteenth Century, p. 314.

I4. Nottingham to Coxe, Whitehall, 10 June 1690, National Archives, Kew (London), SP 104/157 f. 1; Coxe to duke of Shrewsbury (Secretary of State), 20 Apr. and 15 June 1690, Bouherau to [Vernon?], 30 Apr. 1690, SP 96/7. Cf. instructions for Paget going to Vienna, 4 Sept. 1689, SP 104/194. In 1690, English policymakers expected the Spaniards to work on the Grisons and the Catholic cantons on William III's behalf, Instructions for lord Dursley as plenipotentiary at the Hague Congress, 20 Feb. 1689-1690, British Library (London), Add. Mss 28,939 f. 16. 
British policy-makers ${ }^{15}$. Broadly speaking, diplomats everywhere, including those sent to Switzerland, had three main day to day functions; representation and the maintenance of good relations between the two sovereigns concerned, negotiation, and the gathering and transmission of intelligence. But these functioned within a framework of larger objectives, some transient others more permanent.

In 1689, at the start of the Nine Years War, the newly-elevated William III had one pressing concern, i.e. to have other states acknowledge him and his wife as king and queen. This was no easy matter, not least because Louis XIV of France and the Pope continued to recognise the exiled James II as king and pressed other catholic states to do the same. The matter continued to affect Britain's foreign relations following the decision in 1701 to settle the crown on the Protestant house of Hanover when queen Anne died as was expected without direct heirs, excluding not only James II's son, the "Old Pretender", but also other, Catholic claimants, including the princes of the house of Savoy. These developments meant that the British succession was an issue in international affairs until at least the abortive Jacobite rebellion of $1745-1746^{16}$. As far as Switzerland was concerned, the Catholic cantons did not recognise the first Hanoverian, George I, as king until $1716^{17}$.

Besides securing his recognition by the Swiss, William III also hoped, in 1689, to draw them into the coalition he was building against France, not least because France's south-eastern border was the most vulnerable to invasion following Louis XIV's fortress-building programme of the 1680s; this stimulated English hopes of entering France there, fomenting a Protestant revolt in the south which should undermine France's war effort and force Louis XIV to seek peace ${ }^{18}$. William and his allies continued to see the Swiss as a valuable addition to any alliance against France. Thus, in the summer of 1696, towards the close of the Nine Years War, and in order to prevent the conclusion of a separate peace between the Duke of Savoy, Victor Amadeus II, and Louis XIV, the leaders of the anti-French coalition hoped that - in return for a subsidy -

I5. P. Langford, The Eighteenth Century 1688-1815, p. $16 \mathrm{ff}$.

I6. Cf. D. Szechi, The Jacobites.

17. D. B. Horn, Britain and Europe in the Eighteenth Century, p. 316.

I8. Cf. L. A. Robertson, "The Relations of William III with the Swiss Protestants, 1689-1697”, p. 144-145 and Ch. Storrs, “Thomas Coxe and the Lindau Project”. 
the Helvetic Body might join England, the Dutch and the Emperor in guaranteeing the Duke's states, and provide him with troops ${ }^{19}$. The more ambitious of these hopes were disappointed in the Nine Years War and the War of the Spanish Succession (1701/1702-1713/1714), a period in which English diplomacy in the region was crucially re-oriented in this part of Europe, away from the Helvetic Body and in favour of the Savoyard state - guardian of the alpine passages between north Italy and the south of France - as the most obvious collaborator in pursuit of its objectives in the south against France, with important implications for British diplomatic representation in Switzerland. Thereafter, the Duke of Savoy (king of Sicily, 1713-1720; king of Sardinia from 1720) was Britain's "natural" ally there ${ }^{20}$, although aspirations of the sort just mentioned - and a desire to ensure Geneva did not succumb to French pressure but remained neutral - continued to influence British policy in the War of the Austrian Succession (1740-1748) and the Seven Years War (1756-1763) ${ }^{21}$.

Another function of British - as of other - diplomats in Switzerland was the periodic negotiation of agreements, or capitulations, to raise troops there, and the renewal and/or renegotiation of existing accords ${ }^{22}$. Following the failure to secure 4,000 Swiss troops in the opening phase of the Nine Years War ${ }^{23}$, most of the extra troops Britain needed in this period were hired from various Protestant German princes - including Hesse-Kassel and Wurttemberg - or obtained by subsidising the Dukes of Savoy, reducing the need for Swiss troops, but Britain sometimes still looked to Switzerland; in 1734, for example, sir Robert Walpole hoped

19. Cf. comte de la Tour's account of his discussion with the Dutch Pensionary, Anthonie Heinsius, 26 June 1696, AST/Negoziazioni/Svizzera, m. 7/5.

20. Cf. H. M. Scott, “The True Principles of the Revolution”, p. $55 \mathrm{ff}$. and for Pitt at the start of the Seven Years War, D. B. Horn, The British Diplomatic Service 1689-1798, p. 27.

2I. On the need to ensure Genevan neutrality, cf. Villettes to [?], Bern, 19 Dec. 1753, SP 96/34.

22. For the abortive English negotiations for troops in the Nine Years War: L. A. Robertson, "The Relations of William III with the Swiss Protestants, 16891697 ", passim; and in 1745, for Flanders, Minutes of meeting attended by the duke of Newcastle and others, 1 May 1745, SP 36/66.

23. L. A. Robertson, "The Relations of William III and the Swiss Protestants, 16891697 ", passim. 
to secure 6,000 Swiss troops ${ }^{24}$. The American War of Independence, too, saw abortive British efforts to recruit troops in Switzerland ${ }^{25}$. Even when Britain was not itself seeking troops, British diplomats might help the representatives in Switzerland of Britain's allies with their own negotiations for troops ${ }^{26}$; they were also expected to obstruct the troop negociatiations of Britain's enemies ${ }^{27}$.

In 1693, during the Nine Years War, the Dutch minister in Switzerland, Peter Valckenier asserted, in connection with his negotiations for a battalion of troops from Zurich, concluded in May 1693 with some help from Hervart, that the Allies negotiated with reason, the French with money ${ }^{28}$. French diplomatic success in Switzerland certainly owed something to this means ${ }^{29}$. But the truth was that most states, including Britain, resorted to the payment in Switzerland of gratifications of one sort or another, as it had long done elsewhere ${ }^{30}$. The giving of gratifications and pensions was spelled out in Coxe's instructions in $1689^{31}$, but throughout his mission Coxe felt obliged to urge the necessity of paying gratifications to key figures and to make clear that William III's allies and enemies

24. Cf. D. B. Horn, Britain and Europe in the Eighteenth Century, p. 316 and Id., The British Diplomatic Service 1689-1789, p. 32.

25. D. B. Horn, Britain and Europe in the Eighteenth Century, p. 319. Cf. J. F. Erskine, Narrative and memorial of Colonel Erskine and E. Giddey, "J. F. Erskine et son régiment suisse".

26. During the War of the Spanish Succession, when the canton of Fribourg was offended by the Duke of Savoy's discharging a colonel of their canton and incorporating his regiment into another, and sent a herald to Turin to complain, Victor Amadeus ordered his representative, Mellarède, to negotiate a resolution. The Duke also asked the English minister in Turin, John Chetwynd, to have the English envoy in Switzerland, Abraham Stanyan, help to resolve the matter, Chetwynd to Hedges, Turin, 28 Apr. 1706, SP 92/27 f. 301. British diplomats might mediate between their allies and the Swiss in other negotiations; in the summer of 1690, Coxe supported the efforts of the Catholic Duke of Savoy to secure an alliance with the Protestant cantons, Coxe to Shrewsbury, 12 and 15 June 1690, Zurich, SP 96/7.

27. Cf. de la Tour to [cavaliere Ossorio ?], 18 Mar. 1751, AST/Negoziazioni/Svizzera, m. $10 / 3$.

28. Valckenier to Fagel, 28 Apr. 1693, in M. Bokhorst, Nederlands-Zwitserse betrekkingen voor en na 1700 , p. 90 ; L. A. Robertson, "The Relations of William III and the Swiss Protestants, 1689-1697”, p. 161. Cf. also A. de Lange, "Pieter Valckenier”.

29. L. A. Robertson, "The Relations of William III and the Swiss Protestants, 16891697 ”, p. 141 ff., p. 160-161.

30. R. M. Hatton, "Gratifications and foreign policy".

3I. Instructions for Coxe, 20 Aug. 1689, SP 104/157 f. 70. 
in Switzerland were pouring money into the cantons ${ }^{32}$. Perhaps in consequence of the failure of Coxe's mission, William got the message; in 1692 , he did allow a pension of $£ 200$ p.a. to baron Fedal de la Tour, one of those Swiss who had collaborated with Coxe ${ }^{33}$. British ministers in Switzerland continued to believe that money facilitated success in Switzerland; in 1757, commenting on French concern at the progress of Spanish influence in the cantons in recent years, Villettes observed that "as in the last war [that of the Austrian Succession], Spanish gold will get the better of the French ambassador's rhetoric" ${ }^{4}$. Having said that, it was one thing to be promised a pension, another to receive it, because pensions were often irregularly paid and frequently in arrears ${ }^{35}$.

Negotiations - for alliances, for troops, and for loans ${ }^{36}$ - tended to be episodic. So, too, were the representations - official and unofficial - it was sometimes necessary to make to the Swiss authorities; in 1778, for example, during the American War of Independence, Braun was ordered to press the enforcement of the cantons' laws against the export of timber, in order to prevent the French navy securing a supply of this crucial raw material ${ }^{37}$. But every day the diplomat represented his sovereign. This involved upholding the dignity of that sovereign, defending his honour and what was due to him. An infringement of this sort led the comte de Marsay to withdraw for a number of years from

32. Coxe to Shrewsbury, Zurich, 8, 11, and 18 May, SP 96/7. Cf. same to same, Zurich, 21 May and 1 June 1690, Zurich, SP 96/7, for the receipt by the Spanish minister, Casati, and by the French ambassador of money for distribution in this way.

33. Blathwayt to Nottingham, 28 Mar. 1692, Hague, Add. Mss 37991, f. IO; same to same, 14 Apr. 1693, Add. Mss 37992 f. 2.

34. Villettes to Holdernesse, Bern, 22 May 1757, SP 96/36. Ca. 1780, Erskine, in outlining a Swiss official's response to the French ambassador's pressure against his own levy noted that the man received a substantial French pension, J. F. Erskine, Narrative and memorial of Colonel Erskine, p. 21-22.

35. Cf. Blathwayt to Nottingham, 14 Apr. 1693, HMC, Finch, V, p. 75, for baron de la Tour pressing for payment of $£ 200$, half a year's pension, due since end 1692 . In 1690 the Spaniards promised to pay arrears of the pensions they were obliged to give in Switzerland.

36. During the War of the Spanish Succession, Abraham Stanyan negotiated a loan of $£ 150,000$ from the canton of Bern to British government (and received a commission of $0.5 \%$, or $£ 750$ ), Calendar of Treasury Books, vol. XXIV (1710), p. 248-249 and p. 349, cited in D. B. Horn, The British Diplomatic Service 1689-1789, p. 58.

37. Chamier to Braun, St. James', 11 Sept. 1778, SP 96/48; Braun to Weymouth, Bern, 26 Sept. 1778, SP 96/48. 
Geneva in $1734^{38}$, while the denial of the due honours and privileges to George III's representative, Pictet led to the closure of the Geneva mission in $1774{ }^{39}$.

Successive British ministers were expected to maintain good relations with the states to which they were sent. This sometimes involved them in more or less overtly propagandistic activity, including for example the celebration of British successes. In the summer of 1690, Thomas Coxe celebrated William III's victory over the Franco-Irish forces of James II at the battle of the Boyne in Ireland, a victory which ensured that William retained the English throne and was able to channel English resources into the struggle against Louis XIV in Europe; and in November 1691, on the king's birthday, Coxe celebrated that event and final victory in Ireland ${ }^{40}$. British ministers in Switzerland continued to celebrate the monarch's birthday throughout the eighteenth century.

Another ongoing rather than episodic function - although its importance was greater in wartime - was the role of successive British ministers in Switzerland in Britain's intelligence network. There were two aspects to this. For one thing, they oversaw the smooth working of the posts which passed through Switzerland sent by British diplomats in other parts, notably Italy. This was particularly important in wartime, when it was crucial that sensitive correspondence not fall into French hands ${ }^{41}$. The British minister forwarded sensitive material from this

38. Cf. Lettre de M. le Comte de Marsay... aux Magnifiques Seigneurs Sindics et Conseil de la Republique de Geneve, [5 Dec. 1736], copy in National Library of Scotland, Edinburgh.

39. D. B. Horn, Britain and Europe in the Eighteenth Century, p. 322; Id., The British Diplomatic Service 1689-1789, p. 32.

40. Coxe to Shrewsbury, 3 Aug. 1690, Bern, SP 96/7. According to Coxe's bill of expenses, his entertaining on this occasion cost 155 ducats, CSPD, 1693, p. $40 \mathrm{ff}$.

4I. Cf. copy of Fischer's memoire, 9 May 1694, SP 92/26 f. 101; Galway to Trenchard, 25 May and 16 July 1694, SP 92/26 f. 99, 108; Chetwynd to Hedges, Turin, 2 Oct. 1706, SP 92/27 f. 378; same to same, 18 Oct. 1706, Add. 61151 f. 25. In the summer of 1704, Richard Hill, English minister in Turin, sent to Zurich, for onward despatch to London, the treaty recently concluded with the Duke of Savoy, Hill to Hedges, Turin, 19 Aug. and 2 Sept. 1704, NS, W. Blackley (ed.), Diplomatic Correspondence of the Right Hon. Richard Hill, E, p. 409-410 and p. 416 [but same to Lord Treasurer, 2 Sept. 1704, p. 417] and to Hedges, 9 and 19 Sept., and 1 Oct. 1704, p. 418-420 and p. 430-433, Hill to Marlborough, 3 Oct. 1704, Ibid., p. 435-437. 
source throughout the eighteenth century ${ }^{42}$. During the early stages of the Seven Years War, as the British military position deteriorated in Germany, Villettes worried about the security of the posts - not least because the cipher he had been given to encode his despatches was 12 years old, which may say something about the relative unimportance of his mission ${ }^{43}$; since ministers in London shared his concern, arrangements were made on this occasion to send letters to Villettes under cover, to the husband of his sister-in-law, an official in the Swiss postal administration ${ }^{44}$.

But Switzerland's proximity to France also made it an invaluable source of intelligence about enemy activity both there and elsewhere. Useful information might be more or less openly obtained; in June 1690, for example, Coxe reported that the escalating quarrel between the Courts of Versailles and Turin had disrupted business at Lyon, which would have been common knowledge among Swiss merchants and financiers with dealings there ${ }^{45}$. In the War of the Spanish Succession, Stanyan obtained intelligence about the war in Spain from a senior Swiss officer serving in the Bourbon army in Catalonia ${ }^{46}$. During that same conflict, the English military commander, the Duke of Marlborough had urged that "an active stirring minister in Switzerland would be capable of doing more service than anywhere else, both in supporting and encouraging the Protestant cantons and in furnishing the quickest intelligence from all parts" ${ }^{47}$, prompting (abortive) plans for an espionage network based on Geneva ${ }^{48}$.

This intelligence-gathering role continued well after 1713, and extended well beyond Switzerland. In 1753-1754, Villettes reported

42. Villettes to Fox, Bern, 6 Dec. 1755, SP 96/34; same to Pitt, Bern, 17 Apr. 1757, SP 96/37.

43. Villettes to earl of Holdernesse, Bern, 29 May 1757, SP 96/36.

44. Villettes to Robert Wood, Bern, 11 Dec. 1757, SP 96/36.

45. Coxe to Shrewsbury, 22 June 1690, Zurich, SP 96/7. In September 1695, Hervart forwarded to London a copy of the French ambassador's recent memorial presented to the states of Switzerland, Hervart to [?], 21 Sept. 1695, British Library Lansdowne Mss., 849, f. 96.

46. Stanyan to Horatio Walpole, 28 Mar. 1711, HMC, Townshend, p. 86.

47. D. B. Horn, The British Diplomatic Service 1689-1789, p. 31 ; Id., Britain and Europe in the Eighteenth Century, p. 315.

48. D. B. Horn, The British Diplomatic Service 1689-1789, p. 31. 
on developments in Italy ${ }^{49}$, and in 1755 , anticipating the outbreak of another war, urged that he would be far more useful if based not in Bern but in Geneva, where he had to go to consult a physician, which would provide good cover ${ }^{50}$. That same year, ministers in London ordered their representatives abroad to send material to the author of the London Gazette as the British government sought to counter mischievous reporting of foreign affairs in the British press ${ }^{51}$, but of most importance - particularly during the Seven Years War - was the regular intelligence Villettes provided about French naval and other activity in Marseilles, Provence and elsewhere ${ }^{52}$. Villettes also passed on information regarding France's ally, Austria ${ }^{53}$. In later, more peaceful years, the British minister in Switzerland was expected to report on all aspects of the government, finance, and so on of the Helvetic Body ${ }^{54}$, a distinctive new interest in the resources of other states on the part of ministers in London which was a marked feature of the era ${ }^{55}$. One particular area of concern of the British authorities, and which British ministers in Switzerland played a part in monitoring was the activity abroad of Jacobite exiles, adherents of the ousted James II and his son ${ }^{56}$. In 1720, for example, Francis Manning reported the passage through Geneva of lady Mar, who was returning to England to press the restoration of her

49. Villettes to [?], Bern, 19 Dec. 1753, and 9 Feb. 1754 SP 96/34.

50. Villettes to Robinson, Bern, 8 Mar. 1755 SP 96/34. Villettes was given permission, but his contacts in Geneva thought that his presence would provoke the French, causing difficulties for the republic (and for them); he therefore decided to return to Bern, Villettes to earl of Holdernesse, Geneva, 17 May 1755, SP 96/34.

5I. Villettes to Robinson, Bern, 16 Apr. 1755 SP 96/34. For public news sent by Villettes, cf. same to same, Bern, 8 June 1755, SP 96/34.

52. Villettes to Robinson, Bern, 20 Sept. 1755, and same to Fox, Bern, 13 Dec. 1755 SP 96/34; same to Pitt, Bern, 17 Apr. 1757, and same to Holdernesse, Bern, 22 May 1757, SP 96/36.

53. In 1757, for example, he reported the negotiation by the Court of Vienna of loans in Switzerland, Villettes to Pitt, Bern, 17 Apr. 1757 SP 96/34.

54. Halifax to Norton, St. James's, 26 Mar. 1765 SP 96/41 ; D. B. Horn, Britain and Europe in the Eighteenth Century, p. 318. Norton had just arrived in Switzerland. If he complied with this request, his report(s) would represent an invaluable source for the general condition of the Helvetic Body at this time. I have found no such reports.

55. Cf. instructions for lord Mountstuart, going as envoy to Turin, 13 Oct. 1779, SP $92 / 82$.

56. Despite recognising George I as king (above), the catholic cantons still tolerated Jacobite exiles (D. B. Horn, Britain and Europe in the Eighteenth Century, p. 316). 
exiled husband, the Duke of Mar ${ }^{57}$. In 1755, Villettes claimed that the cost of the correspondence he maintained with Neuchatel, where the Jacobite earl Marischal was governor for the king of Prussia, and with Provence, was $£ 200$ annually ${ }^{58}$.

One source of intelligence was a network of correspondents throughout Switzerland. Coxe, for example, based in Zurich, had correspondents at Bern, Soleure, Basel, Coire, Constance, Geneva and elsewhere ${ }^{59}$. His successors did much the same. More than fifty years later, in 1753, for example, Villettes' correspondents in the government of Geneva informed him of new instructions sent to the republic's representative in Turin $^{60}$; following the appointment of a Jacobite governor of Neuchatel (above), if not before, Villettes had correspondent(s) there, too ${ }^{61}$. In 1766, another British resident, William Norton, forwarded to London a copy of a letter received from his correspondent at Lucern which gave valuable information regarding Spanish policy in Switzerland.

Besides giving gratifications, successive British ministers sought to oil the wheels of diplomacy by entertaining members of the local elite. This "social diplomacy" could advance political objectives ${ }^{62}$. Diplomats not only entertained the local elites. Although there was not a substantial diplomatic corps in Switzerland (above), diplomatic communities in the

57. Manning to Craggs, Bern, 20 Mar. 1720, SP 96/50. In the spring of 1754 , Villettes was ordered to find out about a man sent from Rome with letters for the Old Pretender's eldest son, addressed to a Genevan banker who apparently carried on this correspondence, Villettes to earl of Holdernesse, Geneva, 17 May 1755, and Bern, 19 May 1755 SP 96/34. Villettes' contacts in the magistracy of Geneva secured him access to the register of travellers, but identifying the man did not prove easy.

58. Villettes to Robinson, Bern, 8 June 1755, and same to earl of Holdernesse, Bern, 6 Jul. 1755, SP 96/34. Earlier, Coxe's bill of expenses, Mar. 1690-Aug. 1692, included 50 ducats paid to a correspondent in Paris, CSPD, 1693, p. $40 \mathrm{ff}$.

59. Coxe to Shrewsbury, 25 Nov. 1689 and 20 Apr. and 29 May 1690, SP 96/7. Cf. Conte Solaro di Govone to Coxe, Lucerne, 23 Feb. 1690, AST/LM/Svizzera, m. 26.

6o. Villettes to [?], Bern, 19 Dec. 1753, SP 96/34.

6I. Villettes to earl of Holdernesse, Geneva, 17 May 1755, same to same, Bern, 2 Aug. 1755, SP 96/34.

62. Cf. on "social politics" E. Chalus, "Elite Women, Social Politics and the Political World of Late Eighteenth Century England”. Coxe's bills of expenses throw some light on his entertaining of local dignitaries in 1690-1691, especially on the occasions of the various (extraordinary) Diets he requested, CSPD, 1693, p. $40 \mathrm{ff}$. 
cantons could enrich elite social life and facilitate diplomacy ${ }^{63}$. Foreign diplomats often resided in different towns, but could easily reach each other. Thus, on the occasion of the Diet of the Protestant cantons he had convened at Arau to discuss William III's alliance project in June 1690, Coxe was visited by the Savoyard envoy, count Gouvon (or Govone), who was accompanied by his wife and family ${ }^{64}$; and in the spring of 1754, the new Imperial minister, Mareschal visited Zurich to deliver his credentials as resident from The Emperor and Empress, and to call on the British minister, then returned to reside at Basel ${ }^{65}$. These official contacts sometimes bolossomed into what seem like real friendships; this seems to have happened in the case of Coxe and Gouvon. Both men were accompanied by their wives, who seem to have fully participated in the developing amity, suggesting ways in which women could participate in an unofficial way in diplomacy which was otherwise - and particularly in its formal, public operation - a largely masculine world ${ }^{66}$.

Besides these political functions, British ministers in Switzerland in the eighteenth century were expected to look after the growing number of British visitors to Switzerland, some simply passing through, others residing for longer periods - including for example the Stanhopes, who spent ten years in Geneva between 1764 and 1774 - often for educational purposes ${ }^{67}$. Some of these travellers were of the most distinguished rank, including in 1782, George III's son, the Duke of Gloucester visited Geneva incognito, during the Franco-SardinianBernese occupation when there was no British diplomatic presence in the

63. De la Tour to [Ossorio ?], 10 and 13 Dec. 1750 and 18 Mar. 1751, AST/ Negoziazioni/Svizzera, m. 10/3.

64. Coxe's bill of expenses, CSPD, 1693, p. $40 \mathrm{ff}$.

65. Villettes to lord [?], Bern, 31 May 1754, SP 96/34.

66. J. Black, British Diplomats and Diplomacy 1688-1800, p. 17. Coxe's wife travelled to Switzerland while pregnant and gave birth there. This may have been the child which died in the summer of 1690, Coxe to Shrewsbury, Zurich, 9 July 1690, SP 96/7. If a husband was ill and incapable, a wife might write his regular report home, cf. marchesa Desmarches to comte de Saint Laurent, Geneva, 15 Sept. 1745, AST/LM/Geneva, m. 2.

67. On British travellers, cf. V. Cossy, B. Kapossy and R. Whatmore (éds), Genève, lieu d'Angleterre (1725-1814) - Geneva, an English enclave (1725-1814) and P. Vincent, La Suisse vue par les écrivains de langue anglaise, p. 19 ff. For the Stanhopes, cf. DNB, "Charles Stanhope". Necker, secretary to at least one British minister in Switzerland, resigned his post in order to teach history and law to English visitors to Geneva, D. B. Horn, The British Diplomatic Service 1689-1789, p. 38. 
republic, before moving on to Bern ${ }^{68}$. For another, less exalted British visitor, William Wickham, study at Geneva university was followed by marriage into the local elite; it also prepared him for a diplomatic role in Switzerland after $1789^{69}$. It was not only the monarch's British subjects who passed through; in 1753, Bern was visited by professor Haller, of the university of Gottingen - a Hanoverian subject of George II - there to marry off his daughter and to seek one of the leading vacant offices in the canton ${ }^{70}$. Those visitors - and their relations - expected to be helped, particularly those of elevated rank. In 1755, the Duke of Dorset requested that Villettes arrange the incarceration there of Dorset's son, lord John Sackville, whose lifestyle was threatening his own health and the reputation of his family ${ }^{71}$. But British ministers also had to be vigilant, because travellers might be vulnerable. In 1755 Villettes reported a project of the Jacobite governor of Neuchatel to establish a [noble] academy at Neuchatel, which Villettes suspected was intended to infect young English and Scots travellers with Jacobitism ${ }^{72}$.

These various obligations inevitably involved most British ministers in Switzerland in what was their most time-consuming, and often rather tedious task, the writing of despatches to the Secretary of State's office in London ${ }^{73}$, although these sometimes dwindled in frequency and also became rather brief and formal, even formulaic when there was little to report.

Broadly speaking, the responsibilities of British diplomats in Switzerland were much the same as those of British diplomats elsewhere - and those of other states. But on the whole British diplomats in Switzerland did not have overmuch to do by the second half of the

68. According to the Savoyard (Sardinian) representative there, the Duke's presence hindered diplomacy, conte Ferrero della Marmora to [conte Perrone], Geneva, 13, 16, 20, 23 and 27 Aug. and 6 Sept. 1782, AST/LM/Geneva, m. 10.

69. DNB, "William Wickham". His marriage linked Wickham to the British minister in Geneva, Isaac Pictet.

70. Villettes to [?], Bern, 18 Apr. 1753, SP 96/34.

7I. Villettes to Fox, Bern, 27 Dec. 1755, NA/SP/96/34.

72. Villettes to Fox, Bern, 13 Dec. 1755, SP 96/34.

73. Cf. J. Black, British Diplomats and Diplomacy 1688-1800, p. 58. 
eighteenth century ${ }^{74}$. Indeed, in 1757 , the British minister in Madrid, sir Benjamin Keene, wrote to a correspondent:

How often have I told you, and you agree to it, that Swisserland is the country to be employed in, where there are no admirals, no privateers, no trade, nor navigation ${ }^{75}$.

The real importance of Switzerland in British policy and diplomacy had clearly declined dramatically since 1689 , and since there was no royal Court and little by way of a diplomatic community resident in one place, the representatives of the various states tending to reside in different cities, a choice in part determined by religion, related duties were not their $\operatorname{lot}^{76}$. The duties of successive British representatives in Switzerland, finally, did not necessitate a permanent mission, nor did they require the selection of a figure of great ability or high rank, or the appointment of somebody to a high diplomatic rank.

\section{Official and unofficial diplomacy}

According to D. B. Horn, 16 individuals resided in Switzerland as officially accredited representatives - having credentials or creditive letters - of England/Britain between 1689 and $1789^{77}$. Some of these were "permanent", including those sent to Geneva and the Helvetic Body ${ }^{78}$, others were ad hoc missions, including those sent to the Grisons ${ }^{79}$.

74. Villettes to [?], Bern, 17 Jan. 1754, SP 96/34. Typical of an array of miscellaneous tasks of a minor nature which British representatives in Switzerland were charged with, in 1755 Villettes was ordered to help one Boisy, who was commissioned by the Landgrave of Hesse to find a tutor in Switzerland for his grandson, Villettes to Fox, Bern, 6 Dec. 1755, SP 96/34.

75. R. Lodge (ed.), The Private Correspondence of Sir Benjamin Keene, p. 511.

76. Ministers to the Grisons resided at Coire, Coxe to Shrewsbury, 22 June 1690, Zurich, SP 96/7. Ministers to Geneva, obviously, resided there; most British ministers to the Helvetic Body resided at Bern, Basel or Zurich; those of Catholic powers - the Duke of Savoy (king of Sardinia from 1720), the Pope and so on resided at Lucern, Coxe to Shrewsbury, 29 May and 1 June 1690, SP 96/7. From 1782 the king of Sardinia had a resident at Geneva.

77. D. B. Horn, British Diplomatic Representatives 1689-1789, p. 144-150.

78. D. B. Horn, Britain and Europe in the Eighteenth Century, p. 321.

79. Ibid., p. 323. 
The first of these were Thomas Coxe and Philibert de Hervart, baron of Huningen, sent (above) by William III in $1689^{80}$. Unfortunately, fears in and for Geneva meant that while Hervart was allowed to reside in Geneva between 1690 and 1692 he was not received officially as William's representative. Indeed, in the winter of 1690-1691, using bishop Gilbert Burnet (who had spent some months in exile in Geneva in 1685-1686), and again a year later, writing directly to the king, the Genevan authorities asked William not to send a representative to them, for fear of provoking Louis XIV's troops ${ }^{81}$. In 1692, therefore, Hervart removed to Bern, replacing Coxe who was recalled, having failed in his own mission ${ }^{82}$. Hervart remained at Bern, where in 1696 he married into the patrician elite. In the meantime, however, in the summer of 1694, William appears to have decided that he had no need for a minister in Switzerland, and recalled Hervart ${ }^{83}$. Nevertheless, a year later, in the summer of 1695, William's envoy to the Duke of Savoy (and commander of the troops in the Duke's service which had been raised by William and the Dutch), the French Huguenot exile, Henri Massue de Ruvigny, marquis of Galway ${ }^{84}$, recommended that the marquis d'Arsellieres, who had accompanied Coxe to Switzerland in 1689, reside at Geneva and William agreed ${ }^{85}$.

The despatch to Switzerland in 1703 of Dr. William Aglionby by Queen Anne reflected the fact that the Swiss cantons were still seen as a strategic prize in the struggle against France in the War of the Spanish Succession. As the Duke of Shrewsbury - a former Secretary of State then residing on the continent - declared in May 1704:

8o. D. Pedro Ronquillo to marques of Cogolludo, London, 25 Aug. 1689, in D. de Maura (ed.), Correspondencia entre dos Embajadores, vol. 1, p. 123.

8I. L. A. Robertson, "The Relations of William III and the Swiss Protestants 16891697", p. 156-157; A. Chopard, Die Mission des englischen Gesandten Philibert Herwarth in der Schweiz, p. 34. Louis XIV's troops were now more of a threat than before 1690, since they occupied the duchy of Savoy. For Burnet, cf. DNB, "Gilbert Burnet".

82. Coxe's Revocation, 3 Mar. 1692, SP 104/157 f. 77.

83. [?] to [?], 1694, HMC, Finch, II, p. 103-104.

84. DNB, "Henri Massue de Ruvigny, marquis of Galway".

85. Blathwayt to Shrewsbury, Malogne abbey, 15 Aug. 1695, Add. Mss 37,992 f. 108. Coxe to Shrewsbury, Zurich, 18 May 1690, SP 96/7. 
We have been told a long while of great matters the Swiss would do in favour of his Royal Highness [the Duke of Savoy]; and it is certain it were absolutely in their power to turn the balance of this war ${ }^{86}$.

Aglionby was recalled in 1705, but was replaced by Abraham Stanyan, who remained in Switzerland until 1714. The end of the War of the Spanish Succession concluded this cycle of war and with it the intensity of British diplomatic activity in Switzerland. Unusually good relations with France from 1716 may have contributed to the closure of the Bern mission, in $1722^{87}$, although a minister continued to reside at Geneva. The mission to Bern was re-opened in 1743, but for the rest of the eighteenth century, Britain was represented in Switzerland - if at all - by a succession of low-ranking (below) men, whose missions were long, but frequently interrupted by absence, when an even lower-ranking agent would fill in. Such were Francis Manning, James Dayrolle, Armand Louis de St. George, comte de Marsay (who briefly abandoned Geneva between 1734 and 1738, residing instead at Zurich and Bern, above) ${ }^{88}$. In 1738, Manning, who may have been residing in Switzerland in a private capacity, urged the need to restore the British mission there, nobody having resided in the cantons since (Manning himself in) $1722^{89}$. War suggested the need to act on the proposal. In 1743, during the War of the Austrian Succession, Britain and its allies were sufficiently concerned by the success of Spanish diplomacy in Switzerland - attributed as usual to the giving of money and presents, in the Catholic cantons - to consider sending Arthur Villettes there from Turin, where he was British resident ${ }^{90}$. Instead, John Burnaby was sent (and Jerome de Salis to the Grisons), such that the Austrian succession conflict saw an intensity of contact unknown for some decades. Thus was initiated a resumption of continuous relations with the Helvetic Body, Burnaby being followed by Arthur Villettes, Robert Colebrooke, and William Norton. The same

86. Shrewsbury to Hill, Rome, 31 May 1704, W. Blackley (ed.), Diplomatic Correspondence of the Right Hon. Richard Hill, p. 739-740.

87. D. B. Horn, Britain and Europe in the Eighteenth Century, p. 316.

88. Cf. Additional Instructions to earl Waldegrave, 10 Apr. 1738, in L. G. Wickham Legg (ed.), British Diplomatic Instructions 1689-1789, VI; France 1727-1744, p. 203-204.

89. Memorial..., Bern, 8 July 1738, SP 96/50.

90. Villettes to Newcastle, Turin, 8 Feb. 1743, SP 92/47. 
was not true of the Grisons, which saw no British minister after 1750 . As for Geneva, a British minister resided there until 1767 and again between 1772 and 1774. There was no British representative in Geneva after Isaac Pictet's recall in 1774, and only colonel Louis Braun, a chargé, in Bern from 1776 (to 1792). The void was remarked by others; at least twice in 1781, the Savoyard Secretary of State and chief minister, conte Perrone, discussing the ongoing Geneva crisis, urged on the British representative in Turin, lord Mountstuart, that Britain send somebody able to Bern, to exploit anti-French feeling ${ }^{91}$.

But besides the diplomats who resided for years at a time, there were a number of ad hoc missions. These were often, but not only, associated with efforts to secure Swiss troops (above). Exemplary were a number of brief forays into Switzerland in the Nine Years War by the earl of Galway, William III's envoy to the Court of Turin (above) ${ }^{92}$. In the winter of 1693-1694, for example, the newly-appointed Galway travelled from England to Piedmont via Switzerland, where he intended to raise troops, and spent some weeks in Zurich ${ }^{93}$. He returned to Switzerland in succeeding years, following the end of the campaign season, for example at the end of $1694^{94}$. He passed a couple of weeks in Bern, visiting Lausanne and liaising with Huguenot exiles ${ }^{95}$, and no doubt with Hervart ${ }^{96}$. Galway returned to Turin via the cantons of Lucerne and Ury, pressing them to recognise William III as king of England; in the face of their reluctance, the earl urged the distribution of money ${ }^{97}$.

9I. Lord Mountstuart to Hillsborough, Turin, 13 Jan. and 28 Nov. 1781, Add. Mss 36,802 f. 79 and 106.

92. Galway's secretary in Turin, Elias Bouherau, had served Coxe in the same capacity in Switzerland.

93. Memoire for Duke of Savoy from Galway, 27 Nov. 1693, AST/Levata Truppe Straniere, m. 1/25; Galway to [?], Rotterdam, 25 Dec. 1693, SP 92/26, f. 47; Galway to [Blathwayt], Zurich, 31 Jan. 1694, SP 92/26, f. 49; Galway to “monsieur”, 13 Feb. 1694, Zurich, SP 92/26 f. 53. Cf. A. Chopard, Die Mission des englischen Gesandten Philibert Herwarth in der Schweiz, p. $15 \mathrm{ff}$.

94. Galway to Trenchard, Nevay, 15 Oct. 1694, SP 92/26 f. 116; A. Chopard, Die Mission des englischen Gesandten Philibert Herwarth in der Schweiz, p. 21.

95. Galway to Trenchard, Bern, 22 and 31 Oct. 1694, SP 92/26 f. 119 and 124; same to Heinsius, Bern, 27 Oct. 1694, H. J. Van Der Heim, Het archief van den Raadpensionaris Antonie Heinsius, vol. 2, p. 91.

96. Hervart to Trenchard, Bern, 24 Oct. 1694, SP 96/9 [rec'd. 6 Nov. 1694].

97. Galway to Trenchard, Turin, 14 Dec. 1694, SP 92/26 f. 128 [rec'd 29/12/1694]. From Bern, Galway communicated with admiral Russell, commander of the 
Galway also stopped off in Milan, where he helped deputies from the cantons in their negotiations with the governor, the Spanish marques de Leganes and again urged Swiss recognition of William III ${ }^{98}$. Galway was in Switzerland again in the winter of 1695-1696, again negotiating, with Zurich and Berne, for troops ${ }^{99}$, although he gave out that he was simply visiting relations; he also went to Vevay, at a time when the deputies of the Protestant cantons were at Geneva, to see whether he could offer any help ${ }^{100}$. Galway visited Vevay with the blessing of the Duke of Savoy, who wished to offer to the Swiss the French Huguenot troops then in his service (under Galway, above) ${ }^{101}$; Zurich and Bern welcomed the offer of the troops ${ }^{102}$, but the negotiation fell through. Finally, at the end of 1696, Galway was again in Switzerland, seeking to obtain money for his troops, which were leaving Italy and heading for the Low Countries via Switzerland ${ }^{103}$.

Besides the officially credited minister, whether resident or one-off, a diplomatic role of sorts was played by some of the British travellers in Switzerland. In 1743, for example, the Scots earl of Lindsay, residing briefly in Geneva, used his influence with the magistrates there - and money, it was claimed - to prevent the Spanish and French Courts securing passage for their troops into the Milanese via Domodossola ${ }^{104}$. Some decades later, in 1763, lord Stanhope, then residing in Geneva (above), informed British ministers of the republic's reluctance to accept as British resident colonel James Pictet ${ }^{105}$. Following the outbreak of

English fleet in the Mediterranean, via Alexander Stanhope, the English minister in Madrid, Stanhope to Galway, Madrid, 2, 16, and 30 Dec. 1694, Kent Record Office, $\mathrm{U} / 1590 / 015 / 4$.

98. Hervart to Trenchard, Bern, 27 Dec. 1694, SP 96/9.

99. Galway to Shrewsbury, Rolle (Switz), 25 Nov. 1695, and Turin, 17 Dec. 1695, HMC, Buccleuch, 1, part 2, p. 257 and 274.

Ioo. Galway to Shrewsbury, 12 Nov. 1695, HMC, Buccleuch, 2/1, p. 252.

Ior. Galway to Lexington, Vevay in Switz, 23 Nov. 1695, Add. 46,539 f. 85.

I02. Galway to Shrewsbury, Rolle (Switz), 25 Nov. 1695, HMC, Buccleuch, 2/1, p. 257.

I03. Galway to Lexington, 28 Nov. 1696, Milan, Add. Mss 46,539 f. 190.

I04. R. Rolt, Memoirs of the Life of the Late Right Honourable John Lindesay, Earl of Craufurd and Lindesay, p. 354; D. B. Horn, The British Diplomatic Service 1689-1789, p. $40-41$.

I05. Stanhope to Pitt, 1763, Geneva, Papers of sir Edward O’Bryen Hoare, accessed via the National Archives website. 
the War of American Independence, a group of Swiss Protestant army officers wishing to serve Britain approached the British government not through its absentee official representative, Norton, or his deputy, Braun, in Bern but sought to open negotiations through a Scottish visitor to Switzerland, James Francis Erskine ${ }^{106}$.

Norton's absence was one indication of the secondary importance of the official British missions to Switzerland in the later eighteenth century; another was the low diplomatic rank held by most of the men sent there. When the system of resident diplomats developed, in fifteenth century Italy, there were relatively few ranks in what was a very simple hierarchy; the basic distinction was between ambassadors and lesser ministers, or residents. By the eighteenth century, however, the earlier simplicity had developed into something much more elaborate. At the top was still the ambassador, almost always now “extraordinary'. Below, the rank of resident was declining in status and increasingly overshadowed by the relatively new rank of envoy extraordinary; envoys were often given the added dignity of plenipotentiary or minister plenipotentiary. Practice varied from state to state but increasingly conformed to this hierarchy. Firmly at the bottom of the hierarchy were the charge, secretary and so on. All sovereigns, royal and republican, were acutely aware of what was happening, and alert to the distinctions, as were those they sent abroad to represent them ${ }^{107}$.

Britain sent no ambassadors to Switzerland between 1689 and 1789 . This contrasts markedly with the number of ambassadors sent by Britain to the French Court in the same period ${ }^{108}$, and with French representation in Switzerland; between 1689 and 1789, of 35 diplomats listed by Livet as despatched to the Helvetic body, 19 - well over half - went as ambassador, almost all of the remainder enjoying the rank of chargé $e^{109}$. As for Spain, of the 10 men residing there on behalf of the Catholic King between 1689 and 1789 (really only to 1769), only one went as

I06. D. B. Horn, Britain and Europe in the Eighteenth Century, p. 319; J. F. Erskine, Narrative and memorial of Colonel Erskine.

107. M. S. Anderson, The Rise of Modern Diplomacy 1450-1919, p. 83-84. For one contemporary view, cf. F. de Callières, The Art of Diplomacy, p. $101 \mathrm{ff}$. Callieres' treatise was originally published in 1716 .

I08. Cf. list in D. B. Horn, British Diplomatic Representatives 1689-1789, p. $11 \mathrm{ff}$.

I09. G. Livet (éd.), Recueil des Instructions aux Ambassadeurs et Ministres de France, $\mathrm{XXX} / 1$, p. clix-x. 
ambassador, two as envoy extraordinary, 4 as chargé d'affaires, 2 as resident, the last as minister plenipotentiary ${ }^{110}$. Equally striking was the fact that, after an initial period in which the appointment of envoys extraordinary was favoured (Coxe, Hervart, Aglionby and Stanyan) between 1689 and 1714, with one further appointment at this rank during the War of the Austrian Succession (de Salis) ${ }^{111}$, the remaining nine individuals listed by Horn were all appointed at the inferior rank of chargé d'affaires, secretary, minister and/or minister resident ${ }^{112}$. There were many variables which influenced the rank at which a diplomatic appointment was made, including the social status of the individual concerned ${ }^{113}$ and the cost; in 1752 , Villettes' annual salary as minister in Switzerland was $£ 1095$, plus $£ 400$ in extraordinaries, far less than what ambassadors and envoys received ${ }^{114}$. Clearly, the status of the British mission to Switzerland declined as the century went on.

\section{The men}

Few of the British diplomats in Switzerland in the eighteenth century have entries in the Oxford Dictionary of National Biography (DNB), which says something about their unimportance, their inferior rank and their undistinguished careers. Few were successful; Coxe was not. Equally, few were admired; in December 1744, during the War of the Austrian Succession, the Savoyard representative in Switzerland, the marquis de Desmarches, commenting on reports from London which anticipated 10,000 Swiss entering English and Dutch pay (in the service of Desmarches' own master, king Charles Emanuel III of Sardinia) thought that if this was to be done, England would need a more capable minister in Switzerland than Burnaby ${ }^{115}$. On the whole the men

IIo. D. Ozanam, Les diplomates espagnols du XVIIIe siecle, p. 505.

III. Cf. D. B. Horn, The British Diplomatic Service 1689-1789, p. 43.

II2. The 16 names given by Horn do not include an additional 5 mentioned as acting as chargé d'affaires in the absences of Marsay between 1728 and 1745, or Jean Gabriel Catt, secretary (below).

II3. D. B. Horn, The British Diplomatic Service 1689-1789, p. 28.

II4. D. B. Horn, "The Cost of the Diplomatic Service, 1747-1752".

II5. Marchese Desmarches to comte de Saint Laurent, Geneva, 30 Dec. 1744, AST/ LM/Geneva, m. 2. 
who represented Britain in Switzerland in the eighteenth century do not enjoy a great reputation, But who and what sort of men were they, and how did their diplomatic mission to Switzerland fit into their overall biography?

Just over half - nine - of the 16 men identified by Horn were English; there were no Scots, although these were securing a growing number of appointments within Britain's diplomatic service in the eighteenth century ${ }^{116}$. Of the nine, only Stanyan merits his own entry in the $D N B^{117}$, although both Burnaby and Dayrolle are mentioned in the entries for other members of their families ${ }^{118}$, and Norton is found in the potted biographies of MPs in the History of Parliament series. None of these men was of the most elevated social status. Coxe was a cousin of the politician, Hampden ${ }^{119}$, and Norton the son of the Speaker of the House of Commons; an eldest son, he was sent to Switzerland aged 23, but spent hardly any time there - about eight months of a possible 228 - suggesting the appointment may have been a sinecure, and in 1789 succeeded his father as second baron Grantley ${ }^{120}$. But the other English diplomats sent to Switzerland in the eighteenth century were of more obscure origin and background.

Of the remaining men, at least four - Hervart (or Herwarth) ${ }^{121}$, d'Arsellières, the comte de Marsay, and Villettes (1702-66) ${ }^{122}$, five if we include Galway - were French Huguenot exiles or their descendants, part of the larger Huguenot diaspora ${ }^{123}$, and all except Villettes were titled nobles. This Huguenot presence in British public life was marked after $1688^{124}$, although Hervart had lived in England since

II6. D. B. Horn, The British Diplomatic Service 1689-1789, p. $115 \mathrm{ff}$.

II7. Cf. O. Field, The Kit-Cat Club, for Stanyan's membership of this Whig society.

II8. DNB, "Sir William Burnaby" and "Solomon Dayrolle".

II9. Coxe to Shrewsbury, Zurich, 30 Jan. 1690, SP 96/7.

I20. L. Namier and J. Brooke, The House of Commons 1754-1790, III; Members K-Y, p. 217-218; Pictet fils to [Lascaris?], Geneva, 10 May 1776, AST/LM/Geneva, m. 10.

I2I. There is an entry in DNB, "Philibert Hervart".

I22. Cf. the details in E. Tonetti (a cura di), Corrispondenze Diplomatiche Veneziane da Napoli, p. 342. Apparently, Villettes lent books to Pietro Giannone, who was then a prisoner in Savoy, after having been lured there (1736) from Genevan territory.

I23. Cf. the entry for Hervart's cousin, in DNB, "Esther d'Hervart”.

I24. R. Gwynn, Huguenot heritage, passim. 
1670, sitting in Parliament ${ }^{125}$. The presence of Huguenots in the diplomatic sphere reflected - at least in the decades immediately following the Revolution - an essential want of experience of foreign experience in England just when William III and Anne needed it most and turned to foreigners for it ${ }^{126}$, and a reluctance of English and British subjects to serve abroad. Hervart, Galway and Villettes all established themselves in Britain. For Villettes, the most obscure of those with a Huguenot background, the diplomatic career enabled him to insert himself, or rather his family, into both British and Genevan society. He served in Turin for nearly 17 years (1732-1749), initially as secretary to the earl of Essex, Britain's first (and only) ambassador to that Court in the eighteenth century, then as secretary and resident following Essex's return to England. Villettes was then sent to Switzerland in 1749, remaining there for 13 years, and marrying (1750) the daughter of a French financier, who brought him a good dowry ${ }^{127}$. In the autumn of 1753 , Villettes, reporting rumours of a war in Italy, appeared to be angling for the vacant post of resident at Venice, but without success ${ }^{128}$. Villettes returned to England in 1762 after 30 years absence, dying in 1776 aged 74; there his son, William Anne Villettes, born in Bern in 1754, embarked on a successful military career, culminating in his appointment as British Commander-in-Chief in the Mediterranean (1802) and Lieutenant Governor of Jamaica (1807), where he died in $1808^{129}$.

Reacting against William III's employment of foreigners, Parliament enacted legislation which prevented the monarch from giving credentials to foreigners, although it was possible to circumvent this by giving them credentials in the king's capacity as elector of Hanover; this happened with Marsay and Pictet ${ }^{130}$. Indeed, the remaining men - and possibly

I25. A. Chopard, Die Mission des englischen Gesandten Philibert Herwarth in der Schweiz, p. 4 ff. ; DNB, "Philibert Hervart".

I26. Cf. J. Lowther, Memoir of the reign of James II, p. 10.

I27. Bouer to [?], 9 June 1750, AST/LM/. Geneva, m. 3.

I28. Villettes to lord [?], Bern, 18 Apr. 1753, SP 96/34.

I29. $D N B$, "William Anne Villettes". His two brothers having died unmarried, the male line died out, although on the death of Arthur Villettes his daughter had returned to Geneva with her mother, where she married a member of the Turrettini family, Annual Register, p. 87-88. Ca. 1788-1790, the son, visiting his widowed mother in Geneva, met there and gained the favour of another of George III's sons then touring Switzerland, the Duke of Kent, father of the future Queen Victoria.

130. D. B. Horn, The British Diplomatic Service 1689-1789, p. 113-114. 
four men mentioned by Horn as acting as charge during Marsay's various absences ${ }^{131}$ - appear to have been Swiss ${ }^{132}$. Those who were employed included members of the Pictet family (of Geneva). As early as 1745 , one Pictet, previously in the Savoyard service, hoped apparently to enter that of Britain ${ }^{133}$. This may have been the same Pictet, who was a reformed officer in the military service of the United Provinces ${ }^{134}$, and/or count James Pictet (Geneva, 1763-1767), who was later appointed Gentleman of the Chamber by George III ${ }^{135}$. Pictet's son, Isaac Pictet (Geneva, 1772-1774) was charge d'affaires for 2 years, and was promised by the Secretary of State, the earl of Rochford, that he would replace Norton as soon as some post was found for the latter in England. In 1776, Pictet enlisted the support of king Victor Amadeus III of Sardinia in his efforts to put pressure on the ministers of George III to honour this promise ${ }^{136}$. As for Jerome de Salis (the Grisons, 1743-1750), he appears to have been a relative of the colonel Salis who visited England in $1709^{137}$. Among the advantages for the British government of employing Swiss was that they could exploit their local connections, kin and so on. Thus, Colonel Braun was a scion of one of the leading families of Bern and was connected by marriage with many of the rest ${ }^{138}$,

I3I. Reynaud (1728), Martin (1732), Tronchin (1740) and Necker (1745). These are not included in the 16 listed by Horn.

132. The number and proportion would have been greater if George I had been allowed to employ St Saphorin as his representative in Switzerland in 1716, but Bern, which had in 1701 refused to receive St Saphorin, one of its own subjects as the representative of another sovereign, the Emperor, refused him again, as representative of George I, who sent him instead to Vienna, DNB, "Saint Saphorin". For the earlier episode, cf. Th. Gehling, Ein europaischer Diplomat am Kaiserhof zu Wien, p. $15 \mathrm{ff}$.

I33. Gorzegno to Ossorio, camp at Popolo, 8 May 1745, AST/LM/Inghilterra, m. 51. I34. Pictet fils to [Lascaris?], Geneva, 10 May 1776, AST/LM/Geneva, m. 10.

I35. Count Picter to [Lascaris?], Geneva, 16 July 1777, AST/LM/Geneva, m. 10.

I36. Pictet fils to [Lascaris ?], Geneva, 10 May 1776, AST/LM/Geneva, m. 10. The British minister in Turin, Lynch, promptly received from the Sardinian secretary of State, the marquis d'Aigueblanche, a petition from Pictet; according to Aigueblanche, while the king of Sardinia could not interfere, it would greatly please him if the petition succeeded because of his regard for Pictet, Lynch to Weymouth, Turin, 19 May 1776, SP 92/80/13. Subsequently, the (erroneous) news that Pictet had been appointed to succeed Cat [sic] at Bern was said to have given great satisfaction in Turin, same to same, Turin, 22 June 1776, SP 92/80/18.

137. SP Foreign, Military Expeditions, 87/4/11 and 87/5/25.

I38. J. F. Erskine, Narrative and memorial of Colonel Erskine, p. 38. 
which Erskine was able to make use of when seeking to recruit men in 1778; Braun - although not officially ordered to help Erskine enlist men for the East India Company - gave him letters of introduction to his own friends and relations ${ }^{139}$. But the use of natives could also be problematic; this was certainly the case with colonel James Pictet, whom the Genevan authorities refused to admit as British minister (above), not least because of his interference in politics there ${ }^{140}$; they also refused to accept his son ${ }^{141}$.

How far were these men professionals, men with appropriate, specialist training and pursuing a career in diplomacy? Burnaby was one of the graduates of a scheme to prepare men for the diplomatic service by establishing Regius chairs of modern history at the universities of Oxford and Cambridge (1724) ${ }^{142}$. He then served as secretary in Paris to earl Waldegrave, before going to Sweden and Switzerland, which appears however to have been his last diplomatic appointment ${ }^{143}$. Burnaby's career reveals that some of the men sent to reside in Switzerland on behalf of the British government certainly had diplomatic experience. Aglionby had earlier been appointed to Turin. As for Stanyan he had been secretary in both Constantinople, Venice and Paris, his appointment as envoy in Switzerland thus representing a promotion, and in he 1712 prepared a memorandum suggesting major changes - improvements - to the management of Britain's foreign affairs, although it was not acted upon ${ }^{144}$. Dayrolle had been Trumbull's secretary at Constantinople. Another who fitted into this category was Jean Gabriel Catt, who began his career as secretary to Thomas Robinson (1st baron Grantham) during the War of the Austrian Succession, for 8 years, first in Vienna and then at Aix-la-Chapelle, before working as Villettes' secretary for another 8 years at Bern, then 2 years to Colebrook, before being

I39. Braun to Weymouth, Bern, 26 Sept. 1778, SP 96/48. J. F. Erskine, Narrative and Memorial of Colonel Erskine, p. 22-23.

I40. Cf. Memorandum, containing copies of relevant docs, 1766, SP 78/269.

I4I. D. B. Horn, British Diplomatic Representatives 1689-1789, p. 150.

I42. Ch. Firth, Modern Languages at Oxford 1724-1929, p. 3 ff.; D. B. Horn, The British Diplomatic Service 1689-1789, p. 131.

I43. In 1752, he was receiving a pension of sorts while awaiting a posting, D. B. Horn, “The Cost of the Diplomatic Service, 1745-1752”, p. 608.

I44. Reflections upon the Management of our Foreign Affairs, [April 1712], SP 96/15; cf. D. B. Horn, The British Diplomatic Service 1689-1789, p. 2. 
given responsibility himself (1764-1765). He then acted as secretary to Norton, but after nearly 22 years of service, foreseeing destitution, in 1768 - and again in 1769 following Norton's return - he requested some sort of reward, possibly a pension, from the British government ${ }^{145}$. To some extent these men were professionals, although we should not exaggerate the extent to which any diplomatic "service" was professional in any modern sense in the eighteenth century ${ }^{146}$. And experience was no guarantee of capacity. Villettes had not been a brilliant success in Turin. He wrote excessively long despatches, and was on one occasion rebuked for it ${ }^{147}$; but, for all his words, he often failed to inform ${ }^{148}$. Clearly, however, he was thought capable of filling the limited requirements of the Swiss residency.

Relevant experience might help explain why a man was appointed (to Switzerland) but important too were connections, political and family. This is evident in the case of Coxe, who may have been sent to Switzerland because of William III's obligations to his family and friends in the wake of his seizure of the English throne ${ }^{149}$. Despite his failure in Switzerland, Coxe hoped to secure another posting, angling for the more important post at The Hague at the end of 1693. However, the then Secretary of State, sir John Trenchard, was certain that king William would not employ Coxe, having been informed by the earl of Nottingham that Coxe had agreed to go to New England but not gone. Coxe's informant's comment reveals much about contemporary politics and appointments; "I always told you how your commerce with Lord Nottingham would end. Do you think he can serve a man sincerely that comes out of our family", confirming that family connections remained important in appointments after $1688^{150}$. As for Arsellières, he was

I45. J. G. Catt to [?], Bern, 13 Jan. 1768, SP 96/43. Cf. same to same, Bern, 15 July 1769 (following the return of Norton from leave).

I46. J. Black, British Diplomats and Diplomacy 1688-1800, p. 2.

I47. Apparently, king George II thought Villettes' letters were sometimes "an extraordinary length", Newcastle to Villettes, 3 Feb. 1743/4, SP 92/49.

I48. Cf. Ossorio to Gorzegno, London, 8 Nov. 1746, AST/LM/Inghilterra, m. 52.

I49. A. Cunningham, The History of Great Britain from the Revolution in 1688 to the Accession of George I, vol. 1, p. 107, in D. B. Horn, The British Diplomatic Service 16891789, p. 102.

I50. [?] to Coxe, London, 9 Nov. 1693, CSPD, 1693, p. 395-396. 
known both to the Huguenot Shombergs and to William III's confidant, viscount Sidney ${ }^{151}$.

Equally pertinent is the question, why did men want to serve the king in Switzerland, especially given that it was often a difficult life, in which salaries and costs might go unpaid for long periods ${ }^{152}$. For some, it was simply a route to something better at home ${ }^{153}$.

\section{Perceptions of Switzerland}

How did British diplomats perceive, respond to their exposure to Swiss institutions, politics and society? Very few penned the sort of wideranging end of mission survey, or relation, of the sort associated with Venetian diplomats, although Aglionby prepared an account of his negotiations which is now in the National Archives at Kew ${ }^{154}$. But Aglionby's survey was not published as was Stanyan's Account of Switzerland (1714) ${ }^{155}$. Nevertheless, although few of their observations were made public, Britain's diplomats did frequently comment on, generalise about Switzerland, its institutions and way of life, observations which throw some light on the mentalité of the British ministers in Switzerland in this period. In the case of most of these men, there was frequently a critical, moralising tone to their observations, in which the corruption of a simple people was to the fore. Villettes, for example, in the context of the Spanish troop capitulations which he reported in 1755 referred to corruption as something especially likely to happen in the smaller, poorer cantons ${ }^{156}$. Later that same year, Villettes thought it would be difficult to find a suitable governor in Switzerland for the grandson of

I5I. Coxe to Shrewsbury, Zurich, 18 May 1690, SP 96/7.

I52. Coxe to Shrewsbury, Zurich, 17 and 20 Apr., 11 and 21 May, and 13 July 1690, SP 96/7. Coxe was already owed six months salary and $£ 700$ in extraordinary allowances, in the spring of 1690 .

153. For Hervart, cf. Matthew Prior to Lord and Lady Lexington, Hague, 31 Dec. 1694, in H. Manners Sutton (ed.), The Lexington Papers, p. 25-26.

154. Cited in M. Meier, Die diplomatische Vertretung Englands in der Schweiz im 18. Jahrhundert, p. 129.

I55. Cf. A. Zeerlander, "Die politische und literarische Mission des englischen Gesandten Abraham Stanyan in der Schweiz, 1705-1713”. I56. Villettes to Robinson, Bern, 4 Sept. 1755, SP 96/34. 
the Landgrave of Hesse - which he had been asked to help in (above) - because of the total want of education there and the widespread influence of French manners, resulting in the introduction of luxury and vices in the republican state ${ }^{157}$. Just how far observations of this sort were not simply an attempt to fend off an unwelcome task or justify in advance a diplomatic failure is debatable, but the complaint of Swiss corruption, and of the decline of republican simplicity and virtue, was a commonplace of British diplomatic reports between 1689 and 1789.

\section{Conclusion}

According to Lucien Bély, Switzerland's place in the diplomacy of early modern Europe has been relatively neglected ${ }^{158}$. The observation is just, but so too is the neglect, since Switzerland chose not to play a major role in international affairs. British diplomacy in eighteenth century Switzerland reflected that fact. Initially, after 1689, English ministers sought to bring the Swiss into the anti-French coalitions, but they were forced to acknowledge that this was unlikely to happen; thereafter, down to 1789, British diplomacy had less ambitious concerns. This was reflected in the fact that Britain sometimes had a restricted presence in Switzerland. Even when there was a British representative there, the minister was of relatively humble origins, enjoying a fairly junior rank, and often absent, his place occupied by an even humbler figure of local (in this case, Swiss) extraction. While some of those sent to Switzerland could be said to be professional diplomats, for none was Switzerland a stage in a glittering diplomatic career ${ }^{159}$. Equally, the Swiss mission does not easily fit into H. M. Scott's developing diplomatic culture, but it is arguable that the latter - resident, noble, francophone - was not as dominant as one which might be more typically characterised as intermittent or absent, non-noble (though not entirely obscure) and

I57. Villettes to Fox, Bern, 6 Dec. 1755, SP 96/34. Nevertheless, Villettes identified one M. Daulbonne, a Swiss captain in Dutch service. Daulbonne proved difficult only because of his low (military) rank.

158. Cf. L. Bély, “Conclusion”, p. 373.

I59. By contrast, the Savoyard comte de Viry after a mission to Switzerland, passed to London and was finally appointed Secretary of State in Turin, cf. Ch. Storrs, "Savoyard Diplomacy in the Eighteenth Century (1684-1798)". 
anglophone (except when French-speakers were employed). Indeed, it is arguable that the low-ranking (in all senses) men were the real workhorses of British diplomacy in the eighteenth century ${ }^{160}$. Switzerland enjoyed a new importance in the 1790s, as a centre of the struggle against revolutionary France ${ }^{161}$. But that is another story.

Christopher STORRS

University of Dundee

I60. This included, in Turin for example, Thomas Potter (chargé, 1768-1769), Louis Dutens (secretary and later charge, 1764-1765), Robert Liston (chargé, 1782-1783; he went onto a distinguished diplomatic career), and William Higden (chargé, 1783).

I6I. D. B. Horn, Britain and Europe in the Eighteenth Century, p. 319; DNB, "William Wickham". 


\section{APPENDIX}

British Diplomats in Switzerland, 1689-1789

1. Thomas Coxe (1689-1692); envoy extraordinary; Zurich.

2. Philibert de Hervart, baron de Heunniguen (1689-1702); envoy extraordinary; Geneva and (1692-) Bern.

3. Marquis d'Arsellières (1695-1710); without character; Bern and Geneva.

4. Dr. William Aglionby (1702-1705); envoy extraordinary; Zurich.

5. Abraham Stanyan (1705-1714); envoy extraordinary; Zurich, Bern, Grisons.

6. Francis Manning (1708-1722); charge, secretary, and resident; Bern and Grisons.

7. James Dayrolle (1710, 1715-1717); resident; Geneva.

8. Armand Louis de St. George, comte de Marsay (1717-1762).

9. John Burnaby (1743-1750); minister; Bern.

10. Jerome de Salis (1743-1750); envoy extraordinary; Grisons.

11. Arthur Villettes (1749-1762); minister; Zurich and Bern.

12. Robert Colebrooke (1762-1765); minister; Zurich and Bern.

13. Colonel James, comte de Pictet (1763-1767); minister; Geneva.

14. William Norton (1765-1783); minister; Bern.

15. Isaac Pictet (1772-1774); chargé; Geneva.

16. Colonel Louis Braun (1776-1792); chargé; Bern. 


\section{BIBLIOGRAPHY}

\section{Abbreviations}

Add. Mss: Additional Manuscripts

AST: Archivio di Stato, Turin

CSPD, 1693: Hardy, William John (ed.), Calendar of State Papers Domestic, 1693, London, HMSO, 1908.

CSPD, 1695: Hardy, William John (ed.), Calendar of State Papers Domestic, 1695, London, HMSO, 1908.

DNB: Matthew, Colin, Harrison, Brian and Goldman, Lawrence (eds), Oxford Dictionary of National Biography, Oxford, Oxford University Press, 1993-2006.

HMC: Historic Manuscripts Commission

LM: Lettere Ministri

SP : State Papers

\section{Studies}

Anderson, Matthew S., The Rise of Modern Diplomacy 1450-1919, Harlow, Longman, 1993.

Bell, Gary M., A Handlist of British Diplomatic Representatives 15091688, London, Royal Historical Society, 1990.

BÉly, Lucien, "Conclusion", in L'invention de la diplomatie. Moyen AgeTemps modernes, éd. Lucien Bély, Paris, PUF, 1998, p. 373-374.

Black, Jeremy, "The Revolution and the Development of English Foreign Policy", in By Force or By Default? The Revolution of 1688-1689, ed. Eveline Cruickshanks, Edinburgh, John Donald, 1989, p. 134-158.

—, A System of Ambition? British Foreign Policy 1660-1793, Harlow, Longman, 1991. 
—, British Diplomats and Diplomacy 1688-1800, Exeter, Exeter University Press, 2001.

Blackley, W. (ed.), Diplomatic Correspondence of the Right Hon. Richard Hill, Envoy Extraordinary from the Court of St. James to the Duke of Savoy, 2 vols, London, John Murray, 1845.

BoKHORst, Matthijs, Nederlands-Zwitserse betrekkingen voor en na 1700. Eerste deel; 1685-1697, Amsterdam, H. J. Paris, 1930.

Brewer, John, The Sinews of Power. War, Money and the English State 1688-1783, London, Unwin, 1989.

Callières, François de, The Art of Diplomacy, ed. H. M. A. KeensSoper and K. W. Schweizer, Leicester, Leicester University Press, 1983.

Chalus, Elaine, "Elite Women, Social Politics and the Political World of Late Eighteenth Century England", Historical Journal, 43 (2000), p. 669-697.

Chopard, Adrien, Die Mission des englischen Gesandten Philibert Herwarth in der Schweiz, Affoltern am Albis, Buchdruckerei Dr. J. Weiss, 1932.

Cossy, Valérie, Kapossy, Bela and Whatmore, Richard (éds), Genève, lieu d'Angleterre (1725-1814) - Geneva, an English enclave (17251814), Genève, Editions Slatkine, 2009.

Cunningham, Alexander, The History of Great Britain from the Revolution in 1688 to the Accession of George I, 2 vols, London, A. Strahan and T. Cadell, 1787.

ERskine, James Francis, Narrative and memorial of Colonel Erskine, relative to a regiment, raised on the borders of Switzerland, for the service of the Easty-India-company of England, 1782.

Field, Ophelia, The Kit-Cat Club, London, Harper, 2008.

Firth, Charles, Modern Languages at Oxford 1724-1929, London, Oxford University Press, 1929.

GeHling, Theo, Ein europaischer Diplomat am Kaiserhof zu Wien, Bonn, Ludwig Ruhrscheid Verlag, 1964.

Gibss, Graham, "The Revolution in Foreign Policy", in Britain after the Glorious Revolution, ed. Geoffrey Holmes, London, Macmillan, 1969, p. 59-79.

Giddey, E., "J. F. Erskine et son régiment suisse”, Schweizerische Zeitschrift für Geschichte, 4, (1954), p. 238-259. 
Gwynn, Robin, Huguenot heritage, Brighton, Sussex Academic Press, 2001 (2nd ed.).

Hatton, Ragnhild M., "Gratifications and foreign policy. AngloFrench rivalry in Sweden during the Nine Years War", in William III and Louis XIV 1680-1720, ed. Ragnhild M. Hatton and John S. Bromley, Liverpool, Liverpool University Press, 1968, p. 68-94.

Historic Manuscripts Commission, Buccleuch, 3 vols, London, HMSO, 1899-1926.

—, Finch, 5 vols, London, HMSO, 1913-2004.

Horn, David Bayne, "The Cost of the Diplomatic Service, 1747-1752", English Historical Review, 43 (1928), p. 606-611.

—, British Diplomatic Representatives 1689-1789, London, Royal Historical Society, 1932.

—, The British Diplomatic Service 1689-1789, Oxford, Oxford University Press, 1961.

-, Britain and Europe in the Eighteenth Century, Oxford, Oxford University Press, 1967.

LAnge, Albert de, "Pieter Valckenier. Ein Überblick über sein Leben und Werk", in Pieter Valckenier und das Schicksal der Waldenser um 1700, hrsg. von A. de Lange und G. Schwinge, Heidelberg/ Ubstadt-Weiher/Basel, 2004, p. 61-107.

Langford, Paul, The Eighteenth Century 1688-1815, London, A. and C. Black, 1976.

Livet, Georges (éd.), Recueil des Instructions aux Ambassadeurs et Ministres de France, 2 vols, Paris, 1983.

Lodge, Richard (ed.), The Private Correspondence of Sir Benjamin Keene, K.B., Cambridge, Cambridge University Press, 1938.

Lowther, John, Memoir of the reign of James II, York, T. Wilson and R. Sawyer, 1808.

Manners Sutton, H. (ed.), The Lexington Papers, or Some Account of the Courts of London and Vienna at the conclusion of the seventeenth century, London, John Murray, 1851.

Maura, Duque de (ed.), Correspondencia entre dos Embajadores. Don Pedro Ronquillo y el marques de Cogolludo, 2 vols, Madrid, Consejo Superior de Investigaciones Cientificas, 1951-1952.

Mскаy, Derek and Sсотт, Hamish M., The Rise of the Great Powers 1648-1815, Harlow, Longman, 1983. 
Meier, Markus, Die diplomatische Vertretung Englands in der Schweiz im 18. Jahrhundert, Basel, Verlag von Helbing and Lichtenhahn, 1952.

Namier, Lewis and Brooke, John, The House of Commons 1754-1790, New York, Oxford Univ. Press, 1964, 3 vols.

Onnekink, David (ed.), War and Religion after Westphalia 1648-1713, Farnham, Ashgate, 2009.

Ozanam, D., Les diplomates espagnols du XVIII e siecle, Madrid/ Bordeaux, Publication de la Casa de Velazquez et de la Maison des Pays Ibériques, 1998.

Robertson, L. A., "The Relations of William III with the Swiss Protestants, 1689-1697", Transactions of the Royal Historical Society, 4th series, 12 (1929), p. 137-161.

Rolt, Richard, Memoirs of the Life of the Late Right Honourable John Lindesay, Earl of Craufurd and Lindesay, London, H. Kopp, 1753.

Rотт, Edouard, Histoire de la représentation diplomatique de la France auprès des Cantons suisses et leurs alliés et de leurs Confédérés, 10 vols, Berne, Alcan, 1900-1935.

Scotт, Hamish M., "The True Principles of the Revolution; The Duke of Newcastle and the Idea of the Old System", in Knights Errant and True Englishmen. British Foreign Policy 1600-1800, ed. Jeremy Black, Edinburgh, John Donald, 1989, p. 55-91.

-, "Diplomatic culture in old regime Europe", in Cultures of Power in Europe during the Long Eighteenth Century, ed. Hamish M. Scott and Brendan Simms, Cambridge, Cambridge University Press, 2007, p. 58-85.

Storrs, Christopher, "Thomas Coxe and the Lindau Project", in Dall'Europa alle Valli Valdesi. Atti del Convegno Il Glorioso Rimpatrio 1689-1989, a cura di Albert de Lange, Torino, Claudiana, 1990, p. 199-214.

—, "Savoyard Diplomacy in the Eighteenth Century (1684-1798)", in Politics and Diplomacy in Early Modern Italy. The Structure of Diplomatic Practice 1450-1800, ed. Daniela Frigo, Cambridge, Cambridge University Press, 2000, p. 210-253.

- (ed.), The Fiscal-Military State in Eighteenth Century Europe, Farnham, Ashgate, 2009.

STUcki, Heinzpeter, "Pieter Valckenier in Zürich", in Pieter Valckenier und das Schicksal der Waldenser um 1700, hrsg. von A. de Lange 
und G. Schwinge, Heidelberg/Ubstadt-Weiher/Basel, 2004, p. 123-140.

Szechi, Daniel, The Jacobites. Britain and Europe 1688-1788, Manchester, Manchester University Press, 1994.

Tonetti, Eurigio (a cura di), Corrispondenze Diplomatiche Veneziane da Napoli. Dispacci, vol. XVII, Roma, Istituto Poligrafico e Zecca dello Stato, 1994.

Van Der Heim, Hendrik Jacob, Het archief van den Raadpensionaris Antonie Heinsius, 3 vols, Hague, Martinus Nijhoff, 1867-1880.

Vincent, Patrick, La Suisse vue par les écrivains de langue anglaise, Lausanne, Presses Polytechniques et Universitaires Romandes, 2009.

Wickham LegG, L. G. (ed.), British Diplomatic Instructions 1689-1789, VI; France 1727-1744, London, Royal Historical Society, 1930.

Zeerlander, A., "Die politische und literarische Mission des englischen Gesandten Abraham Stanyan in der Schweiz, 17051713", Berner Zeitschrift für Geschichte und Heimatkunde (1942), p. $87-102$. 
